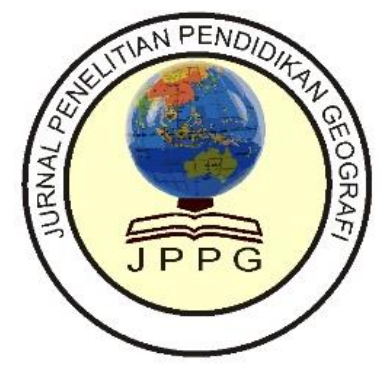

Volume 4 No. 4 Oktober 2019

p-ISSN: 2477-8192 dan e-ISSN: 2502-2776

\title{
PENERAPAN MODEL PROBLEM BASED LEARNING (PBL) UNTUK MENINGKATKAN HASIL BELAJAR SISWA PADA MATERI POKOK GEJALA GEOGRAFI DALAM KEHIDUPAN SEHARI-HARI SMAN 1 RAHA
}

\author{
Isman Harnas ${ }^{1}$, Ramli ${ }^{2}$, Sitti Kasmiati ${ }^{3}$ \\ ${ }^{1}$ Program Studi Pendidikan Geografi \\ Universitas Halu Oleo \\ Email: ismanmades@gmail.com \\ ${ }^{2}$ Program Studi Pendidikan Geografi \\ Universitas Halu Oleo \\ Email: ramlilombe@gmailcom \\ ${ }^{3}$ Program Studi Pendidikan Geografi \\ Universitas Halu Oleo \\ Email: sittikasmiati@gmail.com
}

(Received: 5 September; Accepted: 29 Oktober; Published: 31 Oktober 2019)

(C)2019 - Jurnal Penelitian Pendidikan Geografi. Ini adalah artikel dengan akses terbuka dibawah licenci CC BY-NC-4.0 (http://creativecommons.org/licenses/by-nc/4.0).

\begin{abstract}
:
SMAN 1 Raha is one of the schools in Muna Regency which is the object of research studies because of the low geography learning results, this is because only $43 \%$ of the semester results of students who meet the Minimum submission Criteria The main objective of this study is to describe the learning activities of grade X IIS2 students taught with the Problem Based Learning (PBL) model on the subject matter of geography symptoms in daily life, to describe teacher teaching activities Who teach using the model of Problem Based Learning $(P B L)$ on the subject matter of geography symptoms in daily life. As well as to describe the learning results of geography of grade X students IIS2 SMA Negeri 1 Raha. This type of research is class action research (PTK) conducted with two cycles. The data in the study is qualitative and quantitative data obtained from observation sheets and study results tests. From the results of data analysis obtained by applying the problem-based learning model, student learning activities increased with an average score of 3.2 Good category, teacher teaching activity increased with average score of 3.6 good category and results Learning Geography of Grade $X$ students IIS2 SMAN 1 Raha increased with an average rating of 82, with a learning submission of $81 \%$ or there were 13 students with a value of $\geq 72$ per geographical KKM.
\end{abstract}

Keywords: Problem Based Learning Model, Geography Symptoms, SMA Negeri 1 Raha Muna Regency.

\section{ABSTRAK}

SMAN 1 Raha adalah salah satu sekolah di Kabupaten Muna yang menjadi objek penelitian peneliti karena hasil belajar geografi yang masih rendah, hal ini dikarenakan hanya 43\% hasil ulangan semester siswa yang memenuhi Kriteria ketuntasan minimal. Tujuan utama penelitian ini adalah Untuk mendeskripsikan aktivitas belajar siswa kelas X IIS ${ }^{2}$ yang diajar dengan model Problem Based Learning (PBL) pada materi pokok gejala geografi dalam kehidupan sehari-hari, untuk mendeskripsikan aktivitas mengajar guru yang mengajar dengan menggunakan model Problem Based Learning (PBL) pada materi pokok gejala geografi dalam kehidupan sehari-hari.Serta untuk mendeskripsikan hasil belajar geografi siswa kelas XIIS ${ }^{2}$ SMA Negeri 1 Raha. Jenis penelitian adalah 
Penelitian Tindakan Kelas (PTK) yang dilaksanakan dengan dua siklus. Data dalam penelitian adalah data kualitatif dan kuantitatif yang diperoleh dari lembar observasi dan tes hasil belajar. Dari hasil analisis data diperoleh hasil bahwa dengan menerapkan model problem based learning, aktivitas belajar siswa meningkat dengan skor rata-rata 3,2 berkategori baik, aktivitas mengajar guru meningkat dengan skor rata-rata 3,6 berkategori baik dan hasil belajar geografi siswa Kelas X IIS ${ }^{2}$ SMAN 1 Raha meningkat dengan nilai rata-rata 82, dengan ketuntasan belajar 81\%atau terdapat 13 siswa dengan nilai $\geq 72$ sesuai KKM geografi.

Kata Kunci: Problem Based Learning, Gejala Geografi, SMA Negeri 1 Raha Kabupaten Muna

PENDAHULUAN $\quad$ tersebut, seperti menggunakan model

Menurut Hasbullah (2013) terdapat beberapa factor yang mempengaruhi kegiatan proses pembelajaran yang satu sama lain saling mempengaruhi, yaitu: 1) adanya tujuan yang hendak di capai; 2) adanya subjek manusia (pendidik dan peserta didik) yang melakukan pendidikan; 3) yang hidup bersama dalam lingkungan hidup tertentu, dan 4) menggunakan alat- alat tertentu untuk mencapai tujuan.

Menurut Mulyasa (2013) adalah kreativitas guru. Guru dituntut untuk berlaku sekreatif mungkin demi terwujudnya satu kegiatan pembelajaran sesuai konsep dan karakteristik kurikulum. Namun terkadang dalam proses pembelajaran tujuan dari pembelajaran tidak dapat tercapai karena tidak tepatnya pemilihan model pemebelajaran.

Sekolah Menengah Atas Negeri 1 Raha merupakan salah satu bagian dari kegiatan pendidikan. pembelajaran geografi pada sekolah ini belum memadai. Pembelajaran yang masih kurang optimal tersebut terlihat dari proses pembelajaran geografi yang masih banyak mengalami kendala. Kendala dalam proses pembelajaran geografi teridentifikasi sebagai berikut, pertama, siswa kurang aktif dalam proses pembelajaran.

Dalam mengikuti proses pembelajaran masih banyak siswa yang tidak memperhatikan guru, mereka masih sibuk berbicara sendiri dengan temannya, melamun dan menelungkupkan kepalanuya di atas meja. Hal ini diperkirakan karena model pembelajaran yang digunakan guru hanya berupa pembelajaran Konvensional, sehingga siswa tidak mendapatkan kesempatan untuk mengungkapakan pendapatnya. Kedua, hasil pembelajaran siswa masih rendah. Hal ini dilihat dari hasil ulangan semester satu menunjukan bahwa siswa yang belum tuntas 9 siswa atau $56 \%$ dan yang tuntas 7 siswa atau 43\% dari 16 jumlah siswa, batas ketuntasannya yaitu 70. Sehingga perlu adanya perbaikan untuk meningkatkan hasil belajar siswa pembelajaran PBL.

Menurut Sumantri (2015) pembelajaran berbasis masalah merupakan salah satu model pembelajaran yang berasosiasi dengan pembelajaran kontekstual. Artinya dalam proses pembelajaran siswa dihadapkan pada suatu masalah, kemudian siswa dituntut untuk melakukan pemecahan atas permasalahan sehingga dari pembelajaran tersebut siswa belajar untuk menciptakan keterampilan-keterampilan yang mendasar. Model pembelajaran ini memberikan kesempatan kepada siswa untuk berfikir dan merespon serta saling kerja sama satu sama lain. Dengan model pembelajaran ini, guru dapat mengaktifkan siswa melalui tahapantahapan yang ada, karena model ini menuntut siswa untuk selalu aktif.

Hasil belajar merupakan suatu puncak proses belajar. Hasil belajar tersebut terjadi berkat evaluasi guru. Hasil belajar dapat berupa dampak pengajaran dan dampak penggiring. (Ambarwati dan La Ode Amaluddin, 2019).

\section{METODE PENELITIAN \\ Lokasi Penelitian}

Penelitian ini telah dilakukan di SMA Negeri 1 Raha yang beralamat di jalan Made Sabara, Kecamatan Raha III, Kabupaten Muna, Provinsi Sulawesi Tenggara pada semester Genap Tahun Ajaran 2018/2019.

\section{Subjek Penelitian}

Subjek penelitian ini adalah guru geografi dan siswa kelas X IIS ${ }^{2}$ SMA Negeri 1 Raha, dengan jumlah siswa sebanyak 16 orang yang terdiri dari perempuan berjumlah 7 orang sedangkan laki-laki 9 orang.

\section{Teknik Dan Alat Pengumpulan Data}

Teknik pengumpulan data penelitian ini adalah: 1) Wawancara, dilakukan terhadap siswa dan guru kelas $\mathrm{X}^{1}$ SMA Negeri 1 Raha. untuk memperoleh data yang berkenaan dengan aspek-aspek pembelajaran, penentuan tindakan, dan respons yang timbul sebagai 
akibat dari tindakan yang dilakukan; 2) Observasi, digunakan untuk mengamati perkembangan pembelajaran dengan menggunakan model pembelajaran Problem Based Learning (PBL) yang dilakukan oleh guru dan siswa.

\section{Teknik Analisis Data}

Nilai Rata-Rata

$$
\bar{X}=\frac{\sum X_{i}}{n}
$$

Ket $: \mathrm{X}=$ Nilai rata-rata

$\Sigma x i=$ Jumlah skor yang diperoleh setiap siswa

$\mathrm{N}=$ Jumlah siswa secara keseluruhan

(Sudjana, 2002)

Keberhasilan Aktivitas Mengajar Guru

$\mathrm{KAMG}=\underline{\text { Jumlah skor perolehan }} \times 100 \%$ Jumlah skor maksimum

(Mulyasa, 2013)

Keberhasilan Aktivitas Belajar Siswa

$\% \mathrm{KABS}=$ Jumlah skor perolehan $\times 100 \%$ Jumlah skor maksimum

(Mulyasa, 2013)

Skor Minimal dan Maksimal

$\%=\underline{\text { Jumlah minimal skor }} \times 100 \%$

Jumlah maksimal skor

(Mulyasa, 2003)
$3 \leq \mathrm{Xi}<4 \quad$ : Kategori Baik

$\mathrm{Xi}=4 \quad$ : Kategori Sangat Baik

(Ramly, 2008)

\section{HASIL DAN PEMBAHASAN \\ Data Aktivitas Belajar Siswa}

Data aktivitas siswa kelas X IIS ${ }^{2}$ SMA Negeri 1 Raha selama proses pembelajaran dengan menerapkan Model pembelajaran PBL pada materi gejala-geografi pada kehidupan sehari-hari yang diperoleh menggunakan lembar observasi aktivitas siswa pada setiap pertemuan dengan cara memberikan skor untuk setiap aspek aktivitas yang dipenuhi siswa.

Berdasarkan hasil observasi aktivitas siswa dapat diperoleh gambaran bahwa, hasil aktivitas siswa masih belum memenuhi kriteria ketuntasan minimal yaitu 3,0. Hasil observasi menunjukkan pada pertemuan 1 siklus satu rata-rata aktivitas siswa mencapai 2,5 dengan kategori cukup, dan pada pertemuan kedua siklus 1 masih dengan rata-rata aktivitas siswa mencapai 2,5 dengan kategori cukup. Sehingga rata-rata aktivitas siswa pada siklus 1 masih mencapai rata-rata 2,5 yang berkategorikan cukup.

Untuk mendapatkan gambarann rata-rata aktivitas siswa selama pembelajaran pada siklus I pertemuan I dan II dapat dilihat pada Gambar 1. berikut.

Mengklasifikasikan rata-rata skor aktivitas siswa sebagai berikut:
$1 \leq \mathrm{Xi}<2$
: Kategori Kurang
$2 \leq \mathrm{Xi}<3$
: Kategori Cukup

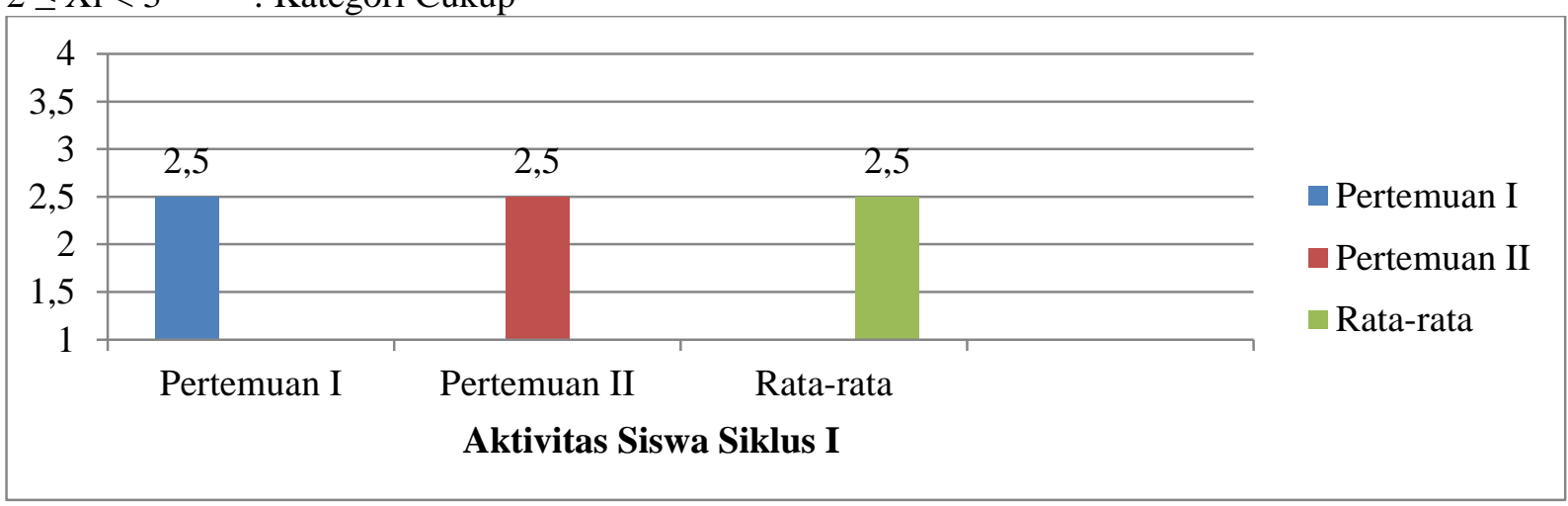

Gambar 1. Grafik Skor Rata-Rata Aktivitas Belajar Siswa I (Analisis Data Primer, 2019)

Berdasarkan gambar 1 di atas, dapat disimpulkan bahwa aktivitas siswa di siklus I masih tergolong cukup hal itu dikarenakan siswa belum terbiasa dengan model pembelajaran berbasis masalah.

Berdasarkan hasil observasi aktivitas belajar siswa pada siklus II pertemuan 1 skor 
men apai 3,1 dengan kategori baik. pada pertemuan kedua siklus 2 skor aktivitas siswa mencapai 3,3 dengan kategori baik. sehingga rata-rata aktivitas belajar siswa pada siklus 2 mencapai 3,2 dengan kategori baik.
Untuk mendapatkan gambaran rata-rata aktivitas siswa siklus II selama pembelajaran dapat dilihat pada gambar berikut:

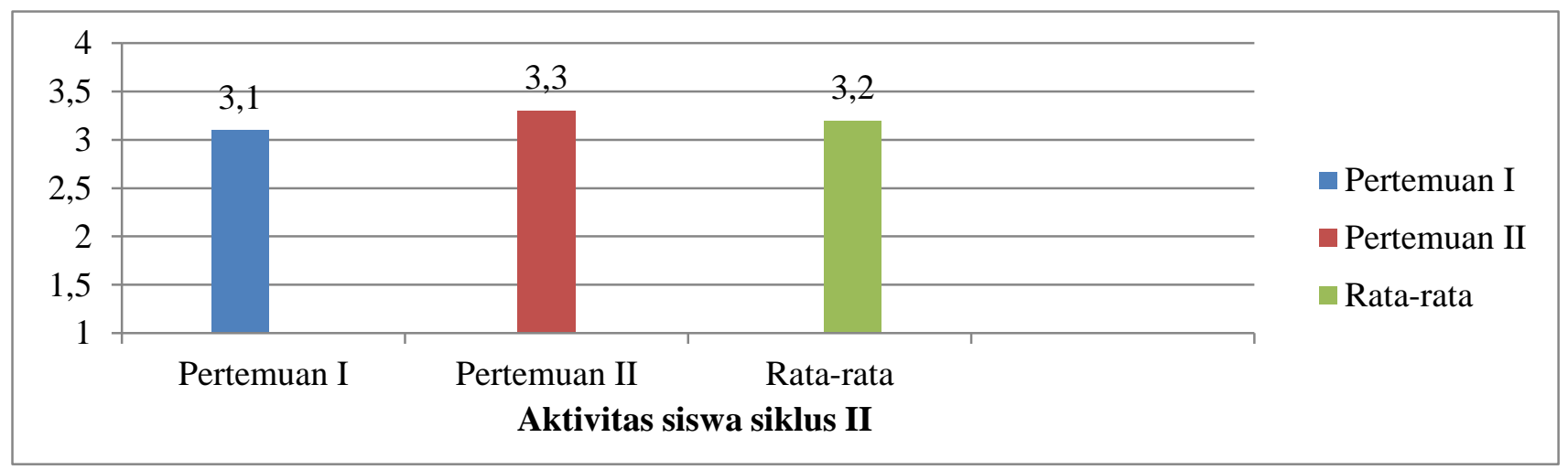

Gambar 2. Rata-Rata Skor Aktivitas Belajar Siswa Pada Siklus II (Analisis Data Primer, 2019).

Berdasarkan gambar 2 di atas menunjukan bahwa, aktivitas siswa telah memenuhi criteria ketuntasan minimal yaitu 3,0. Dimana aktivitas siswa telah mencapai 3,2 yang berkategorikan baik. Sehubungan dengan itu, secara keseluruhan rata-rata aktivitas siswa meningkat dari siklus I ke siklus II.

\section{Data Aktivitas Mengajar Guru Siklus I}

Berdasarkan hasil observasi pada siklus I menunjukkan aktivits guru masih belum memenuhi kriteria ketuntasan minimal yaitu 3,0. Skor aktivitas guru pada pertemuan pertama siklus 1 masih mencapai 2,8 dengan kategori cukup. Sedangkan pada pertemuan kedua siklus 1 rata-rata aktivitas guru masih 2,9 dengan kategori cukup. Sehingga rata-rata aktivitas guru pada siklus 1 masih mencapai rata-rata 2,9 yang berkategorikan cukup.

Untuk lebih jelasnya skor aktivitas guru pada setiap pertemuan pada siklus I dapat dilihat pada gambar 3 berikut.

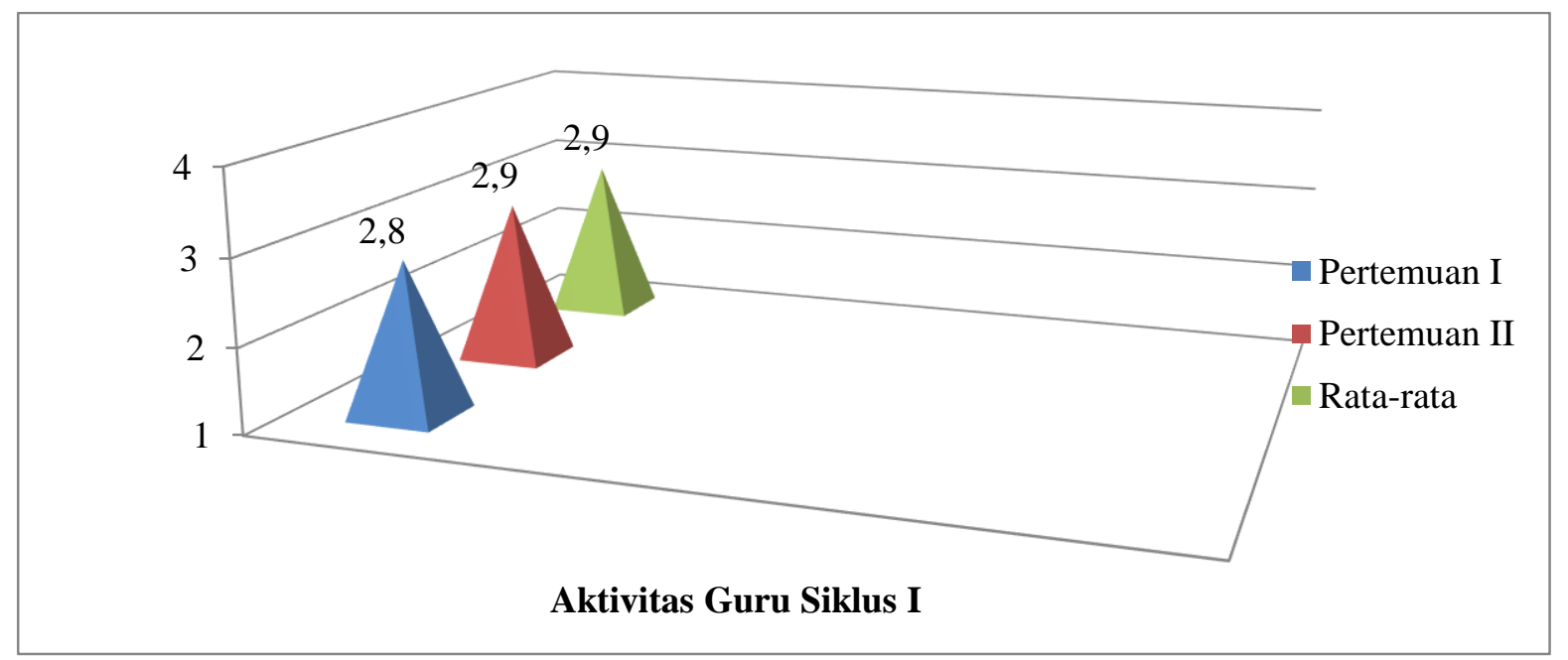

Gambar 3. Grafik Skor Rata-Rata Aktivitas Guru Siklus I (Analisis Data Primer, 2019)

Berdasarkan gambar 3 di atas menunjukkan bahwa, aktivits guru masih belum memenuhi kriteria ketuntasan minimal yaitu 3,0 karena aktivitas guru masih mencapai rata-rata 2,9 yang berkategorikan cukup. Guru nomor 1, 3 dan 15 yaitu membuka pelajaran dan memeriksa kesiapan siswa, guru menyampaikan indikator dan tujuan pembelajaran, dan menutup proses kegiatan pembelajaran. Berdasarkan hasil observasi, aktivitas guru telah memenuhi kriteria ketuntasan minimal yaitu 3,0. Pada peetemuan 
pertama siklus II skor aktivitas mengajar guru mewncapai 3,5 dengan kategori baik. pada pertemjuan kedua siklus II rata-rata skor aktivitas mengajar guru mencapai 3,6 dengan kategori baik. sehingga rata-rata aktivitas mengajar guru pada siklus II telah mencapai rata-rata 3,6 yang berkategorikan baik.

Untuk lebih jelasnya skor rata-rata aktivitas guru pada setiap pertemuan siklus II dapat dilihat pada gambar 4 berikut:

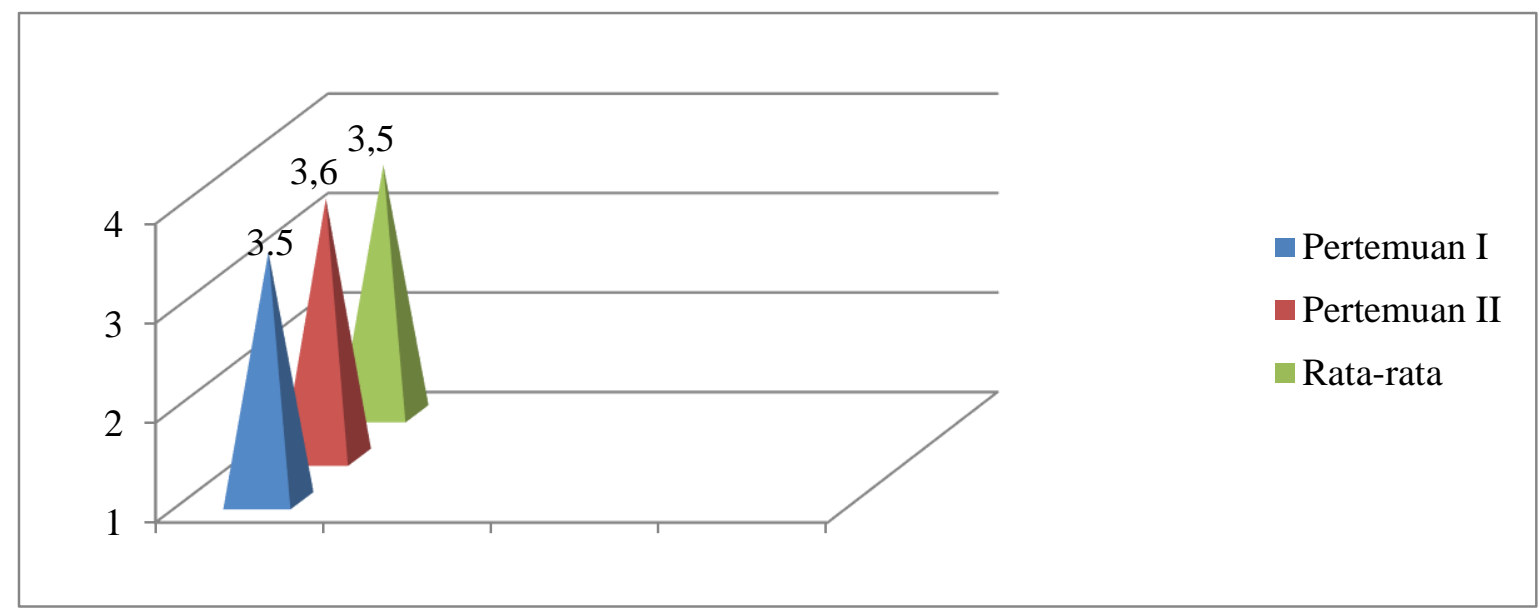

Gambar 4. Rata-Rata Skor Aktivitas Mengajar Guru Pada Siklus II (Analisis Data Primer, 2019)

Sehungan dengan hasil tersebut, maka telah terjadi peningkatan aktivitas mengajar guru dari siklus I ke suklus II.

\section{Data Hasil Belajar Siswa Pada Siklus 1}

Data hasil belajar siswa kelas $\mathrm{X}$ IIS ${ }^{2}$ SMA Negeri 1 Raha pada materi gejalageografi pada kehidupan sehari-hari diperoleh dengan menggunakan lembar tes hasil belajar berupa soal essay yang diberikan pada akhir siklus I.

Hasil penelitian menunjukkan bahwa hasil belajar siswa pada siklus I yang memperoleh skor antara $0-71$ berjumlah 8 orang dengan persentase $50 \%$, sedangkan siswa yang memperoleh skor 72-100 berjumlah 8 orang dengan persentase mencapai $50 \%$, namun itu belum mencapai indikator ketuntasan keberhasilan yaitu $80 \%$ siswa yang mencapai ketuntasan hasil belajar.

Untuk mendapatkan gambaran hasil belajar yang sudah tuntas dan yang belum tuntas siklus I dapat dilihat pada gambar berikut:

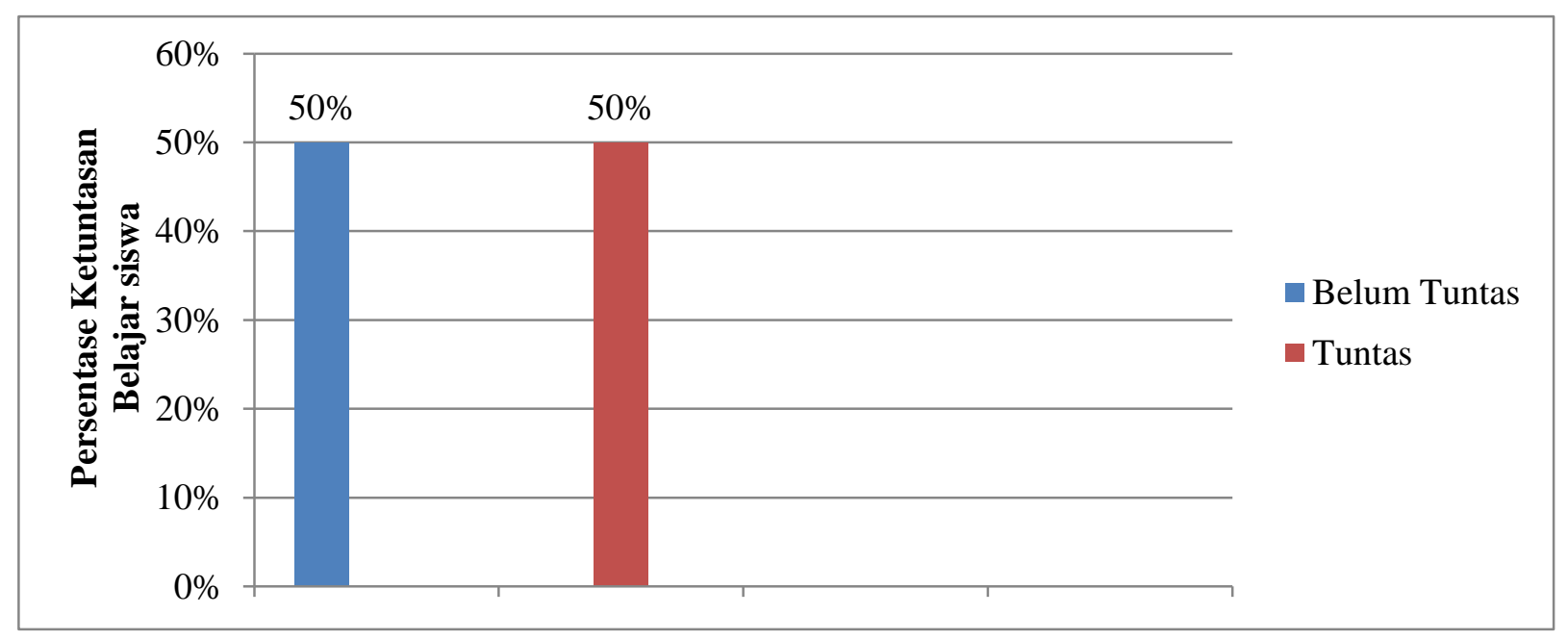

Gambar 5. Hasil Belajar Siswa Pada Siklus I (Analisis Data Primer, 2019)

Data hasil belajar siswa kelas X IIS $^{2}$ Negeri 1 Raha pada materi gejala-geografi pada kehidupan sehari-hari diperoleh dengan menggunakan lembar tes hasil belajar berupa 
soal essay yang diberikan pada akhir siklus II. Berdasarkan hasil analisis data hasil belajar siswa pada siklus II diperoleh hasil bahwa ketuntasan belajar siswa pada siklus II yang memperoleh skor antara 0-71 berjumlah 3 dari 16 siswa dengan persentase $19 \%$. Sedangkan siswa yang memperoleh skor antara 72-100 berjumlah 13 dari 16 siswa dengan persentase ketuntasan $81 \%$ untuk mendapatkan gambaran hasil belajar siswa yang sudah tuntas dan yang belum tuntaspada siklus II dapat dilihat pada gambar berikut:

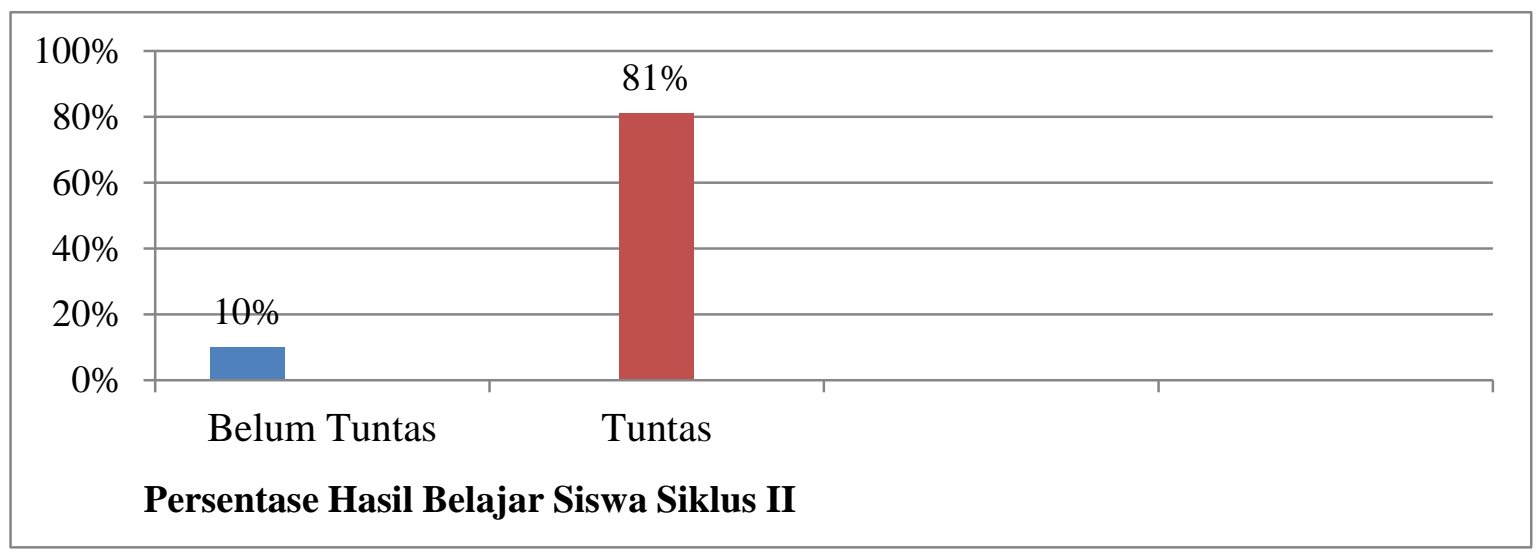

Gambar 6. Hasil Belajar Siswa Pada Siklus II (Analisis Data Primer, 2019)

Berdasarkan hasil ini sudah lebih baik jika dibandingkan dengan skor perolehan siswa siklus I. Dengan demikian indikator ketuntasan belajar siswa telah tercapai dan itu artinya hasil penelitian ini berhasil karena secara klasikal kriteria ketuntasan yang ditetapkan sebagai indikator berhasilnya pembelajaran yaitu $80 \%$ sudah terpenuhi.

\section{PEMBAHASAN}

\section{Aktivitas belajar siswa selama pembelajaran berlangsung}

Pada siklus I berdasarkan hasil analisis deskriptif terhadap aktivitas siswa menunjukan skor rata-rata sebesar 2,5 yang berkategori cukup. Hal tersebut dikarenakan masih ada beberapa aktivitas siswa yang tergolong kurang optimal. Berdasarkan hasil refleksi siklus I ditemukan ada beberapa aktivitas siswa yang belum terlaksana dengan baik salah satunya siswa kurang menjawab pertanyaan yang diberikan oleh guru dengan benar, kurang bekerjasama dalam menyelesaikan tugas kelompok. Oleh karena masih belum optimalnya aktivitas belajar siswa maka diperlukan perbaikan pada siklus selanjutnya. Pada siklus II dari hasil analisis deskriptif terhadap skor rata-rata aktivitas siswa mengalami peningkatan dari aktivitas siswa siklus I. Skor rata-rata aktivitas siswa pada siklus II sebesar 3,2 yang berkategorikan baik.
Aktivitas mengajar guru
pembelajaran berlangsung
Pada siklus I berdasarkan deskiptif aktivitas mengajar guru menunjukan skor rata-rata sebesar 2,9 yang berkategorikan cukup. Hal itu tentu dipengaruhi oleh adanya beberapa aktivitas yang belum terlaksana secara optimal. Hasil refleksi aktivitas mengajar guru pada siklus 1 yang masih rendah diantaranya adalah: Guru melakukan apersepsi tentang materi yang akan dipelajari, Guru mengarahkan kepada tiap-tiap kelompok untuk melakukan kegiatan sesuai dengan petunjuk dalam LKS, Guru mengevaluasi terhadap hasil diskusi siswa.

Berdasarkan hasil refleksi tersebut maka diperlukan pembenahan, agar diperoleh peningktan aktivitas mengajar guru sesuai dengan kriteria ketuntasan yang telah ditetapkan. Pembenahan tersebut dilakukan pada siklus II, pada siklus II berdasarkan hasil analisis deskriptif menjelaskan bahwa aktivitas mengajar guru mengalami peningkatan yang signifikan dengan skor rata-rata sebesar 3,6 yang berkategori baik.

Dengan demikian, dapat disimpulkan bahwa aktivitas belajar siswa dan aktivitas mengajar guru selama proses pembelajaran dari siklus I sampai siklus II mengalami peningkatan. Dengan data ini pula dapat disebutkan bahwa dengan menerapkan Model Pembelajaran Inquiry dapat meningkatan kualitas proses pembelajaran geografi pada 
siswa kelas X IIS ${ }^{2}$ SMAN 1 Raha. Hal ini didukung oleh penelitian Ambarwati, (2019) Penerapan Model Pembelajaran Problem Based Learning (PBL) Untuk Meningkatkan Hasil Belajar Geografi Siswa Kelas Xi Sma Negeri 14 Bombana Pada Materi Pokok Pelestarian Lingkungan Hidup. Hal ini ditunjukan dengan perolehan hasil belajar pada siklus I yang memperoleh skor antara 0-65 berjumlah 10 orang dengan persentase $66 \%$ sedangkan siswa yang memperoleh skor 70100 berjumlah 5 orang dengan persentase mencapai 33\% namun itu belum mencapai indikator ketuntasan keberhasilan yaitu $80 \%$ siswa yang mencapai ketuntasan hasil belajar dan pada siklus II ketuntasanbelajar siswa diperoleh skor antara 0-65 berjumlah 2 dari 15 siswa dengan persentase $13 \%$ sedangkan siswa yang memperoleh skor antara 70-100 berjumlah 13 dari 15 siswa dengan persentase ketuntasan $87 \%$

\section{Hasil Belajar}

Pada siklus I berdasarkan hasil tes belajar siswa diperoleh nilai rata-rata hasil belajar siswa sebesar 45, dengan nilai minimum 13 dan nilai maksimum 80. Secara klasikal dari 16 siswa yang mencapai persentase ketuntasan hasil belajar yaitu 3 siswa atau $19 \%$ dengan nilai $\geq 72$ sesuai KKM geografi yang ditentukan sekolah dan terdapat 13 orang siswa dengan persentase sebesar $81 \%$ yang nilainya belum mencapai KKM yang ditentukan sekolah yaitu 72. Data ini menunjukan bahwa persentase ketuntasan pada siklus I ini belum mencapai target peneliti yaitu minimal $80 \%$ ketuntasan hasil belajar secara klasikal. Data ini juga menjelaskan bahwa dalam pembelajaran ini tampak siswa kurang membaca buku teks yang terkait materi yang dipelajari dan juga siswa kurang aktif serta kurang kompak dalam mengerjakan segala tugas kelompok termasuk LKS.

Setelah melakukan analisis dan refleksi hasil belajar siswa pada siklus I, dicoba dilakukan upaya perbaikan oleh guru dalam proses belajar mengajar agar pada siklus selanjutnya siswa yang memenuhi ketuntasan hasil belajar dapat meningkat lagi seperti yang diharapkan.

Pada siklus II berdasarkan hasil tes belajar siswa, terlihat bahwa hasil belajar siswa memperoleh peningkatan nilai rata-rata hasil belajar siswa menjadi 82, dengan nilai minimum 67 dan nilai maksimum 93. Secara klasikal ketuntasan hasil belajar mencapai target yang ditentukan yaitu $81 \%$, dimana terdapat 13 orang siswa yang memperoleh nilai $\geq 72$ sedangkan jumlah siswa yang tidak tuntas karena hasil belajarnya dibawah KKM atau yang memperoleh nilai $<72$ sebanyak 3 orang atau $19 \%$.

Pada siklus II ini target ketuntasan hasil belajar siswa telah tercapai karena terdapat 81 $\%$ siswa yang tuntas hasil belajarnya. Keadaan ini menunjukkan bahwa peneliti telah berhasil mencapai targetnya. Dalam penelitian ini keberhasilan siswa dalam tes hasil belajar tersebut sebagai indikator yang memberikan gambaran bahwa penerapan model pembelajaran berbasis masalah mampu meningkatkan hasil belajar siswa.

\section{KESIMPULAN}

Berdasarkan hasil penelitian yang diperoleh, dapat ditarik beberapa kesimpulan sebagai berikut: 1) Aktivitas belajar siswa dengan menerapkan model pembelajaran PBL setiap siklus meningkat; 2) Aktivitas mengajar guru dengan menerapkan PBL pada setiap siklus meningkat; 3) Hasil belajar geografi siswa Kelas X IIS ${ }^{2}$ SMAN 1 Raha meningkat setelah menerapkan model PBL pada materi gejala geografi pada kehidupan sehari-hari.

\section{SARAN}

Berdasarkan hasil penelitian terdapat beberapa saran yang berguna bagi penelitian selanjutnya antara lain: 1) Bagi sekolah, khususnya SMAN 1 Raha dapat mencoba menerapkan model PBL ini dalam meningkatkan hasil belajar siswa serta dalam meningkatkan kualitas belajar siswa selama proses pembelajaran; 2) Bagi peneliti selanjutnya, sebagai bahan acuan belajar dan dapat mengaplikasikan model pembelajaran PBL untuk mempertajam kemampuan dalam menerapkan model pembelajaran ini pada kesempatan-kesempatan berikutnya agar memberikan hasil yang jauh lebih optimal.

\section{UCAPAN TERIMA KASIH}

Terima kasih kepada kedua orang tua, Bapak Drs. Ramli, M.Si, selaku pembimbing I dan Dra. H. Sitti Kasmiati, M.Si., serta para reviewer dan editor Jurnal Penelitian Pendidikan Geografi. 
DAFTAR PUSTAKA

Mulyasa. (2013). Pengembangan dan Implementasi Kurikulum 2013. Bandung: PT Remaja Rosdakarya.

Sudjana. (2002). Metoda Statistika. Bandung: Tarsito.

Sumantri. (2015). Strategi Pembelajaran Berorientasi Standar Proses Pendidikan. Jakarta: Kencana Prenada Media Group.
Hasbullah. (2013). Dasar-Dasar Ilmu Pendidikan. Jakarta: Rajawali Pers.

Ambarwati, dan La ode Amaluddin. (2019). Penerapan Model Pembelajaran Problem Basic Learning (PBL) untuk meningkatkan hasil belajar geografi siswa kelas XI SMA Negeri 14 Bombana Pada Materi Pokok Pelestarian Lingkungan Hidup. Jurnal Penelitian Pendidikan Geografi Volume 4 No. 3 Juli 2019. 